\title{
Seasonal and interannual effects of hypoxia on fish habitat quality in central Lake Erie
}

\author{
KRISTIN K. AREND*, ${ }^{*}$, DMITRY BELETSKY ${ }^{\ddagger}$, JOSEPH V. DEPINTO ${ }^{\S}$, STUART A. LUDSIN", \\ JAMES J. ROBERTS ${ }^{\ddagger * * *++}$, DANIEL K. RUCINSKI ${ }^{\S * *}$, DONALD SCAVIA**, \\ DAVID J. SCHWAB ${ }^{\S \S}$ AND TOMAS O. HÖÖK* \\ ${ }^{*}$ Forestry and Natural Resources, Purdue University, West Lafayette, IN, U.S.A. \\ ${ }^{\dagger}$ School of Biological Sciences, Lake Superior State University, Sault Ste. Marie, MI, U.S.A. \\ ${ }^{\ddagger}$ CILER, School of Natural Resources and Environment (SNRE), University of Michigan, Ann Arbor, MI, U.S.A. \\ ${ }^{\S}$ LimnoTech, Ann Arbor, MI, U.S.A. \\ 'Aquatic Ecology Laboratory, Evolution, Ecology, and Organismal Biology, The Ohio State University, Columbus, OH, U.S.A. \\ ${ }^{* *}$ SNRE, University of Michigan, Ann Arbor, MI, U.S.A. \\ ${ }^{++}$Department of Fish, Wildlife, and Conservation Biology, Colorado State University, Fort Collins, CO, U.S.A. \\ ${ }^{\ddagger}$ Graham Environmental Sustainability Institute, University of Michigan, Ann Arbor, MI, U.S.A. \\ ${ }^{\S}$ NOAA Great Lakes Environmental Research Laboratory, Ann Arbor, MI, U.S.A.
}

\section{SUMMARY}

1. Hypoxia occurs seasonally in many stratified coastal marine and freshwater ecosystems when bottom dissolved oxygen (DO) concentrations are depleted below 2-3 mg O $\mathrm{L}^{-1}$. 2. We evaluated the effects of hypoxia on fish habitat quality in the central basin of Lake Erie from 1987 to 2005, using bioenergetic growth rate potential (GRP) as a proxy for habitat quality. We compared the effect of hypoxia on habitat quality of (i) rainbow smelt, Osmerus mordax mordax Mitchill (young-of-year, YOY, and adult), a cold-water planktivore, (ii) emerald shiner, Notropis atherinoides Rafinesque (adult), a warm-water planktivore, (iii) yellow perch, Perca flavescens Mitchill (YOY and adult), a cool-water benthopelagic omnivore and (iv) round goby Neogobius melanostomus Pallas (adult) a eurythermal benthivore. Annual thermal and DO profiles were generated from 1D thermal and DO hydrodynamics models developed for Lake Erie's central basin.

3. Hypoxia occurred annually, typically from mid-July to mid-October, which spatially and temporally overlaps with otherwise high benthic habitat quality. Hypoxia reduced the habitat quality across fish species and life stages, but the magnitude of the reduction varied both among and within species because of the differences in tolerance to low DO levels and warm-water temperatures.

4. Across years, trends in habitat quality mirrored trends in phosphorus concentration and water column oxygen demand in central Lake Erie. The per cent reduction in habitat quality owing to hypoxia was greatest for adult rainbow smelt and round goby (mean: $-35 \%$ ), followed by adult emerald shiner (mean: $-12 \%$ ), YOY rainbow smelt (mean: $-10 \%$ ) and YOY and adult yellow perch (mean: $-8.5 \%$ ).

5. Our results highlight the importance of differential spatiotemporally interactive effects of DO and temperature on relative fish habitat quality and quantity. These effects have the potential to influence the performance of individual fish species as well as population dynamics, trophic interactions and fish community structure.

Keywords: bioenergetics, Great Lakes, growth rate potential, hypoxia, spatially explicit

Correspondence: Kristin K. Arend, School of Biological Sciences, Lake Superior State University, 650 W. Easterday Ave., Sault Ste. Marie, MI 49783, U.S.A. E-mail: karend@lssu.edu 


\section{Introduction}

Nutrient loading to stratified estuarine, coastal marine and freshwater ecosystems can cause seasonal reductions in DO levels in bottom water (e.g. hypolimnetic or sub-pycnocline), resulting in hypoxia (i.e. DO $\leq 2-$ $3 \mathrm{mg} \mathrm{L}^{-1}$ ) (Kennish, 2002; Diaz \& Rosenberg, 2008). Hypolimnetic hypoxia (henceforth referred to as hypoxia) can have a wide range of lethal and sublethal effects on aquatic organisms, including fish. The occurrence of hypoxia and anoxia in coastal waters has increased exponentially since the 1960s because of anthropogenic eutrophication (Diaz \& Rosenberg, 2008). This trend is expected to continue with increasing human population densities (Kennish, 2002) and anticipated temperature and precipitation increases that will exacerbate water column stratification $(\mathrm{Wu}$, 2002; Diaz \& Rosenberg, 2008). Because of these current and projected trends, hypoxia is viewed as a major environmental concern for stratified coastal marine ecosystems (Kennish, 2002; Vaquer-Sunyer \& Duarte, 2008) and lentic freshwater ecosystems (Kling et al., 2003; Fang et al., 2004).

Across a broad range of fishes, hypoxia can cause direct mortality but more commonly results in various sublethal effects (Breitburg, 2002; Shimps, Rice \& Osborne, 2005), such as altered fish physiological processes (Chabot \& Dutil, 1999; Wu, 2002; Fitzgibbon, Strawbridge \& Seymour, 2007), spatial distribution (Aku \& Tonn, 1999; Horppila et al., 2000; Ludsin et al., 2009; Zhang et al., 2009) and predator-prey interactions (Breitburg et al., 1997; Aku \& Tonn, 1999; Horppila et al., 2000; Pollock, Clarke \& Dube, 2007). Collectively, these changes have the potential to affect fish individual performance and, in turn, population dynamics (Wu, 2002 and references therein; Stierhoff, Targett \& Miller, 2006), trophic interactions and energy flow (Pihl et al., 1992; Breitburg et al., 1997, 2003) and community-level characteristics such as species richness (Ludsin et al., 2001).

Susceptibility to hypoxia-related effects can differ among species and life stages. Thus, species-specific responses should be considered when evaluating potential impacts of hypoxia on populations and communities. For example, the DO threshold for physiological and behavioural responses varies both among (Smale \& Rabeni, 1995; Breitburg et al., 2003; Robb \& Abrahams, 2003; Pollock et al., 2007) and within species (Burleson, Wilhelm \& Smatresk, 2001;
Robb \& Abrahams, 2003). Across species, benthic fishes that occupy habitats with frequent hypoxia (e.g. coastal marine ecosystems, wetlands and eutrophic lakes) usually are more tolerant of hypoxia when compared to species occupying colder, more consistently oxygenated habitats (e.g. offshore marine ecosystems, freshwater streams and oligotrophic lakes). Within some species, smaller-bodied or younger individuals appear more tolerant of hypoxia than their larger counterparts (Burleson et al., 2001; Robb \& Abrahams, 2003). However, other studies have found no variation in tolerance with size (Smale \& Rabeni, 1995; Cerezo \& Garcia Garcia, 2004; Valverde, Lopez \& Garcia Garcia, 2006).

Temperature can interact with DO to influence physiological processes and spatial distribution, and thus temperature and DO should be simultaneously considered when attempting to elucidate the effect of hypoxia in a thermally stratified water column. It is well documented that fish species differ in thermal tolerances (Coutant, 1977; Magnuson, Crowder \& Medvick, 1979; Brandt, Magnuson \& Crowder, 1980), and within species there is evidence that younger and smaller individuals often select warmer temperatures than older and larger individuals (Reynolds \& Casterlin, 1978; Brandt et al., 1980). Across species, thermal tolerances have been correlated with DO tolerances (Smale \& Rabeni, 1995), with warm-water fishes generally being more tolerant of low DO levels than cold-water fishes (Pientka \& Parrish, 2002). Hypoxia and temperature can also interact to create a 'thermal-dissolved oxygen squeeze' (sensu Coutant, 1985, 1990; Aku \& Tonn, 1999) in which organisms are confronted by a trade-off between exposing themselves to physiologically compromising temperatures (Coutant, 1985; Horppila et al., 2000) or DO levels (Taylor, Rand \& Jenkins, 2007). For example, a metalimnetic oxygen minimum in Lake Hiidenvesi (Finland) forced smelt (Osmerus eperlanus Linnaeus) to reside in the epilimnion at suboptimally high temperatures, causing a spatial mismatch between smelt and their prey (Horppila et al., 2000). Additionally, hypoxia can indirectly affect fish by reducing access to invertebrate prey (Aku \& Tonn, 1999; Eby et al., 2005; Roberts et al., 2009), as most zooplankton and benthic invertebrates can tolerate lower DO levels than many fishes (Gray, Wu \& Or, 2002; Ludsin et al., 2009). In contrast, epilimnetic piscivores might actually benefit from short-term hypoxia, if it causes their fish prey to 
move up in the water column, thus increasing spatial overlap (Prince \& Goodyear, 2006; Costantini et al., 2008).

The Lake Erie ecosystem supports a variety of ecologically and economically important fishes, which appear to have been differentially affected by hypoxia. Eutrophication-driven hypoxia during the mid-1900s (Rao et al., 2008) may have contributed to the decline of hypoxia-sensitive species (e.g. lake whitefish, Coregonus clupeaformis Mitchill and smallmouth bass, Micropterus dolomieu Lacepède) (Ludsin et al., 2001), through reduced access to benthic habitat and benthic macroinvertebrate prey (e.g. mayflies, Hexagenia spp.)(Reynoldson \& Hamilton, 1993). By contrast, phosphorus abatement programmes initiated during the 1970s reduced the occurrence and extent of hypoxia (Dolan, 1993) and have been suggested as the mechanism responsible for the recovery of these invertebrate and fish populations (Ludsin et al., 2001). More recently, hypoxia has again become problematic in the central basin of Lake Erie (Burns et al., 2005; Matisoff \& Ciborowski, 2005; Hawley et al., 2006; Rucinski et al., 2010), leading to renewed concern about water quality and fishery sustainability.

Here, we use bioenergetic GRP models (Brandt, Mason \& Patrick, 1992) to evaluate the potential impacts of hypoxia on species-specific fish habitat quality in central Lake Erie. Hypoxia-induced reductions in habitat quantity and quality are likely to impose energetic costs on fish, leading to reduced feeding and growth rates (Chabot \& Dutil, 1999; Pichavant et al., 2000; Stierhoff et al., 2006). Hypoxia typically reduces metabolic scope for activity (Claireaux et al., 2000; Jordan \& Steffensen, 2007), which can lead to decreased feeding rates (Chabot \& Dutil, 1999; Stierhoff et al., 2006; Fitzgibbon et al., 2007) and slower growth (Chabot \& Dutil, 1999; Pichavant et al., 2000; Stierhoff et al., 2006). Indeed, variance in food intake because of hypoxia can explain $60-97 \%$ of variance in growth rate (Chabot \& Dutil, 1999; Stierhoff et al., 2006). Consequently, energy budget models represent a potentially useful approach to explore the effects of hypoxia on relative habitat quality and quantity (e.g. Costantini et al., 2008). Growth rate potential estimates are based on standard bioenergetic energy budget models (e.g. Kitchell, Stewart \& Weininger, 1977), in which an individual fish's energy acquisition and availability for growth are influenced by its body size and local environmental conditions (Brandt et al., 1992). This approach allows for the evaluation of potential nonlinear interactions between DO concentrations and other factors (e.g. temperature and prey resources) and quantifies habitat quality based on appropriate spatio-temporal overlap of environmental variables (Brandt et al., 1992; Mason \& Patrick, 1993). We estimated GRP in Lake Erie's central basin over 19 years (1987-2005) for four ecologically and economically important fish species that range in DO and thermal tolerances and habitat and prey preferences.

We consider multiple species and life stages over two decades that span a range of hypoxic conditions. As such, we are better able to understand fish community response to hypoxia in the past and to predict how different fish species are likely to respond to anticipated changes in hypoxia in the future. We hypothesised the following: (i) negative effects of hypoxia on habitat quality and quantity would be most pronounced for benthic and cold-water fish species and less evident for epilimnetic warm-water species; (ii) habitat for juvenile life stages would be less negatively impacted by hypoxia because juveniles tolerate warmer temperatures than adults and might tolerate lower DO levels than larger-bodied fishes; and (iii) interannual trends in fish habitat quality track observed trends in phosphorus loading and hypoxia over the 19- year study period.

\section{Methods}

\section{Focal fish species}

We assessed the effects of hypoxia on four adult fish species and two juvenile species: young-of-year (YOY) and adult yellow perch (Perca flavescens Mitchill), YOY and adult rainbow smelt (Osmerus mordax mordax Mitchill), adult round goby (Neogobius melanostomus Pallas) and adult emerald shiner (Notropis atherinoides Rafinesque). These species and life stages were chosen because they span a range of thermal guilds (e.g. cold water through warm water), feeding guilds (planktivore and benthivore) and relative use of vertical habitat (pelagic zone and benthic zone; Table 1). These species and congeners (e.g. European perch, Perca fluviatilis Linnaeus and European smelt, O. eperlanus) are quite common in aquatic ecosystems throughout North America and Eurasia. Furthermore, 
Table 1 Ecological guilds and bioenergetics model parameter estimates for Lake Erie fishes. Except where noted with an asterisk, parameter estimates are from: yellow perch, Hanson et al. (1997); rainbow smelt, Lantry \& Stewart (1993); round goby, Lee \& Johnson (2005); and emerald shiner, means of the values reported in Hanson et al. (1997) for dace and Duffy (1998) for fathead minnow. YOY: young-of-year; CA: mass dependence function intercept for a $1 \mathrm{~g}$ fish; CB: mass dependence coefficient; CQ: water temperaturedependent coefficient of consumption; CTO: optimum water temperature for consumption; CTM: upper temperature for consumption; CTL: maximum lethal temperature for consumption; CK1, CK4: fraction of the maximum consumption rate for CQ and CTL, respectively; RA: oxygen (g) consumed by a $1 \mathrm{~g}$ fish at RTO; RB: mass dependence coefficient; RQ: rate of respiration increase over low water temperatures; RTO: optimum temperature for respiration; RTM: lethal water temperature for respiration; ACT: activity, i.e. a constant multiplier of resting metabolism; FA, UA: proportion of consumption to egestion or excretion, respectively; FB, UB: egestion or excretion water temperature dependence coefficient; FG, UG: egestion or excretion $P$-value dependence coefficient

\begin{tabular}{|c|c|c|c|c|}
\hline & $\begin{array}{l}\text { Yellow perch } \\
\text { (YOY, adult) }\end{array}$ & $\begin{array}{l}\text { Rainbow smelt } \\
\text { (YOY, adult) }\end{array}$ & $\begin{array}{l}\text { Round goby } \\
\text { (adult) }\end{array}$ & $\begin{array}{l}\text { Emerald shiner } \\
\text { (adult) }\end{array}$ \\
\hline Hypoxia guild & Tolerant & Sensitive & Tolerant & Sensitive \\
\hline Thermal guild & Warm, cool & Warm, cold & Warm & Warm \\
\hline Feeding guild & Benthivore & Planktivore & Benthivore & Planktivore \\
\hline Vertical habitat & Benthic & Pelagic, benthic & Benthic & Pelagic \\
\hline \multicolumn{5}{|l|}{ Consumption } \\
\hline $\mathrm{CA}\left(\mathrm{g} \mathrm{g}^{-1} \mathrm{~d}^{-1}\right)$ & 0.25 & 0.18 & 0.192 & 0.254 \\
\hline $\mathrm{CB}$ & -0.27 & -0.275 & -0.256 & -0.276 \\
\hline $\mathrm{CQ}\left({ }^{\circ} \mathrm{C}\right)$ & 2.3 & 3.0 & 5.594 & 2.25 \\
\hline $\mathrm{CTO}\left({ }^{\circ} \mathrm{C}\right)$ & 29,23 & 16,10 & 24.648 & 25.0 \\
\hline $\mathrm{CTM}\left({ }^{\circ} \mathrm{C}\right)$ & 32,28 & $21,14^{*}$ & 25.706 & 30.0 \\
\hline CTL $\left({ }^{\circ} \mathrm{C}\right)$ & & $26,20^{*}$ & 28.992 & \\
\hline CK1 & & 0.4 & 0.113 & \\
\hline CK4 & & 0.01 & 0.419 & \\
\hline \multicolumn{5}{|l|}{ Respiration } \\
\hline $\mathrm{RA}\left(\mathrm{gO}_{2} \mathrm{~g}^{-1} \mathrm{~d}^{-1}\right)$ & 0.0108 & 0.0027 & 0.00094 & 0.0122 \\
\hline $\mathrm{RB}$ & -0.2 & -0.216 & -0.157 & -0.12 \\
\hline $\mathrm{RQ}\left({ }^{\circ} \mathrm{C}^{-1}\right)$ & 2.1 & 0.036 & 0.061 & 2.35 \\
\hline $\mathrm{RTO}\left({ }^{\circ} \mathrm{C}\right)$ & 32,28 & & & 29.0 \\
\hline $\operatorname{RTM}\left({ }^{\circ} \mathrm{C}\right)$ & 35,33 & & & 33.0 \\
\hline $\mathrm{ACT}$ & 1.0 & & $1.0,3.3^{*}$ & 1.0 \\
\hline \multicolumn{5}{|l|}{ Egestion/Excretion } \\
\hline FA & 0.158 & 0.16 & 0.15 & 0.25 \\
\hline $\mathrm{FB}$ & -0.222 & & & \\
\hline FG & 0.631 & & & \\
\hline UA & 0.0253 & 0.10 & 0.10 & 0.10 \\
\hline UB & 0.58 & & & \\
\hline UG & -0.299 & & & \\
\hline Specific dynamic action & 0.172 & 0.175 & 0.175 & 0.161 \\
\hline Energy density $\left(\mathrm{J} \mathrm{g}^{-1}\right.$ wet $)$ & 4186 & 4814 & 4600 & $7352.0^{+}$ \\
\hline Oxycalorific coefficient $\left(\mathrm{J} \mathrm{g}^{-1}\right.$ wet $)$ & 13560.0 & 13560.0 & 13560.0 & 13560.0 \\
\hline Body weight $(\mathrm{g})$ & $50.0^{\ddagger}, 7.0^{\ddagger}$ & $6.1^{+}, 1.0^{+}$ & $10.0^{\ddagger}$ & $4.5^{\ddagger}$ \\
\hline
\end{tabular}

*Parameter values modified in this paper, as described in the text; ${ }^{\dagger} \mathrm{S}$. Pothoven, personal communication; ${ }^{\ddagger} \mathrm{T}$. Höök, unpublished data.

the species comprise the dominant fish biomass in the offshore waters of central Lake Erie (Pothoven et al., 2009; Roberts et al., 2009) and are ecologically and/or economically important throughout the Laurentian Great Lakes.

\section{Approach}

We used a set of physical and water quality models to generate depth-specific daily estimates of temperature and DO from April to December 1987-2005. We used these estimates to apply species- and life stagespecific bioenergetics-based GRP models to explore the effects of hypoxia on habitat quality of our focal species. To evaluate the effect of hypoxia on habitat quality, we compared GRP for two scenarios: (i) 'normoxia,' in which we assumed that DO levels were above the critical levels throughout the year and (ii) 'hypoxia,' in which DO varied spatially and temporally and affected potential consumption rates via a DO-consumption function (fDO). We compared temporal trends in habitat quality and quantity among

Published 2010. This article is a US Government work and is in the public domain in the USA., Freshwater Biology, 56, 366-383 
years and evaluated the relative impacts of hypoxia on habitat quality.

\section{Model description}

General growth model. Growth rate potential models assume that energy allocated to growth $(G)$ equals the difference between the energy acquired through consumption (C) minus energy lost to metabolism $(\mathrm{M})$ and waste $(\mathrm{W})$ as follows:

$$
\mathrm{G}=\mathrm{C}-(\mathrm{M}+\mathrm{W})
$$

where $\mathrm{G}=$ growth rate, $\mathrm{g}$ assimilated $\cdot \mathrm{g}$ fish ${ }^{-1} \mathrm{~d}^{-1}$

$\mathrm{C}=$ consumption rate, growth rate, $\mathrm{g}$ prey.g fish $^{-1} \mathrm{~d}^{-1}$

$\mathrm{M}=$ respiration rate + standard dynamic action, $\mathrm{g}$ prey.g fish ${ }^{-1} \mathrm{~d}^{-1}$

$\mathrm{W}=$ egestion rate + excretion rate, $\mathrm{g}$ prey.g fish $^{-1} \mathrm{~d}^{-1}$

The bioenergetic effects of temperature and body mass are routinely incorporated into growth rate potential models (Table 1). We also include an effect of oxygen concentration on consumption rates.

Effect of DO on consumption. To model the effects of hypoxia on GRP, we assume consumption decreases at low DO concentrations, based on studies showing significant negative correlations between $\mathrm{DO}$ and consumption and growth (Chabot \& Dutil, 1999; Stierhoff et al., 2006; Brandt et al., 2009; Roberts, 2010). We multiply consumption by a function, fDO, in which values increase linearly with DO concentration from zero to one up to a threshold DO concentration $\left(\mathrm{DO}_{\text {crit }}\right)$, above which fDO equals one. We assume that fDO decreases linearly with DO below $\mathrm{DO}_{\text {crit, }}$ in a similar manner to the response of metabolic rate to DO (Schurmann \& Steffensen, 1997; Cerezo \& Garcia Garcia, 2004; Valverde et al., 2006). We also assume a linear decrease in $\mathrm{DO}_{\text {crit }}$ with temperature (i.e. a fish can tolerate lower DO levels at cooler temperatures), which is consistent with past studies (Schurmann \& Steffensen, 1997; Valverde et al., 2006; but see Cerezo \& Garcia Garcia, 2004 for examples of no temperature effect). Separate fDOs were developed for low DO 'tolerant' and low DO 'sensitive' (henceforth, 'tolerant' and 'sensitive') fish species as described later.

The 'tolerant' fDO was developed from estimates of consumption by adult yellow perch fed until satiated at DO levels between 1.7 and $11.2 \mathrm{mg} \mathrm{L}^{-1}$ in each of three temperature treatments $\left(11,20\right.$ and $27^{\circ} \mathrm{C}$ )(Roberts, 2010). First, we used consumption-rate estimates for individual fish to calculate the temperaturespecific proportion of maximum consumption ( $P$ value) (Fig. 1a). Second, we divided data into cold $\left(11{ }^{\circ} \mathrm{C}\right.$ treatment) and warm $\left(20\right.$ and $27{ }^{\circ} \mathrm{C}$ treatments combined, mean $=23{ }^{\circ} \mathrm{C}$ ) data sets. For each data set, we used regression with break point analysis (e.g. Höök et al., 2007) to estimate $\mathrm{DO}_{\text {crit, }}$ the linear increase in $P$ with $\mathrm{DO}$ up to $\mathrm{DO}_{\text {crit }}$ and the maximum $P$-value $\left(P_{\max }\right)$. Estimated $\mathrm{DO}_{\text {crit }}$ was lower for the cold $\left(11^{\circ} \mathrm{C}\right)$ temperature grouping $\left(2.2 \mathrm{mg} \mathrm{L}^{-1}\right)$ than for the warm $\left(23^{\circ} \mathrm{C}\right)$ temperature grouping $\left(4.2 \mathrm{mg} \mathrm{L}^{-1}\right)$, supporting our assumption that $\mathrm{DO}_{\text {crit }}$ is lower at lower temperatures (Schurmann \& Steffensen, 1997; Valverde et al., 2006). Third, we fit a line between the experimental mean temperatures and fitted $\mathrm{DO}_{\text {crit }}$ values (Fig. 1b). Finally, we divided the fitted $P$-values by $P_{\max }$ so that fDO ranged in value from zero to one. Our final fDO is a split function ranging from zero to one and responding to both temperature and DO: fDO equals ( $\mathrm{DO} \times \mathrm{DO}_{\text {crit }}{ }^{-1}$ ) for DO concentrations less than $\mathrm{DO}_{\text {crit }}$ and $\mathrm{fDO}=1$ for $\mathrm{DO}$ concentrations greater than or equal to $\mathrm{DO}_{\text {crit }}$ (Fig. 1c).

We distinguished between fDO for a tolerant and sensitive fish by assuming that the slope relating $\mathrm{DO}_{\text {crit }}$ to temperature is similar for yellow perch and other fish species (i.e. slope $=0.168 \mathrm{mg} \mathrm{L}^{-1}{ }^{\circ} \mathrm{C}^{-1}$ ) but that the actual value of $\mathrm{DO}_{\text {crit }}$ at a given temperature (i.e. the intercept) will vary among species (Fig. 1b). We used the yellow perch temperature- $\mathrm{DO}_{\text {crit }}$ intercept value of $0.358 \mathrm{mg} \mathrm{L}^{-1}$ for the tolerant fDO, and we applied this relationship for both yellow perch and round goby. The round goby is quite tolerant of low DO, with critical lethal threshold values ranging from 0.4 to $1.3 \mathrm{mg} \mathrm{L}^{-1}$ (Charlebois et al., 1997). Although this $\mathrm{DO}_{\text {crit }}$ is lower than that of yellow perch, round gobies are known to leave areas having $<50-60 \%$ air saturation (Skazkina 1966 in Charlebois et al., 1997), which corresponds roughly to $4.0 \mathrm{mg} \mathrm{L}^{-1}$ at $23{ }^{\circ} \mathrm{C}$. We applied the sensitive fDO to both rainbow smelt and emerald shiner. Rainbow smelt is a cold-water fish species that requires higher DO levels than cool-water species, such as yellow perch. Emerald shiner typically resides in well-oxygenated, epilimnetic waters and is less tolerant of low DO levels than other cyprinids (Matthews \& Maness, 1979). We based the $D_{\text {crit }}$ values for the sensitive 

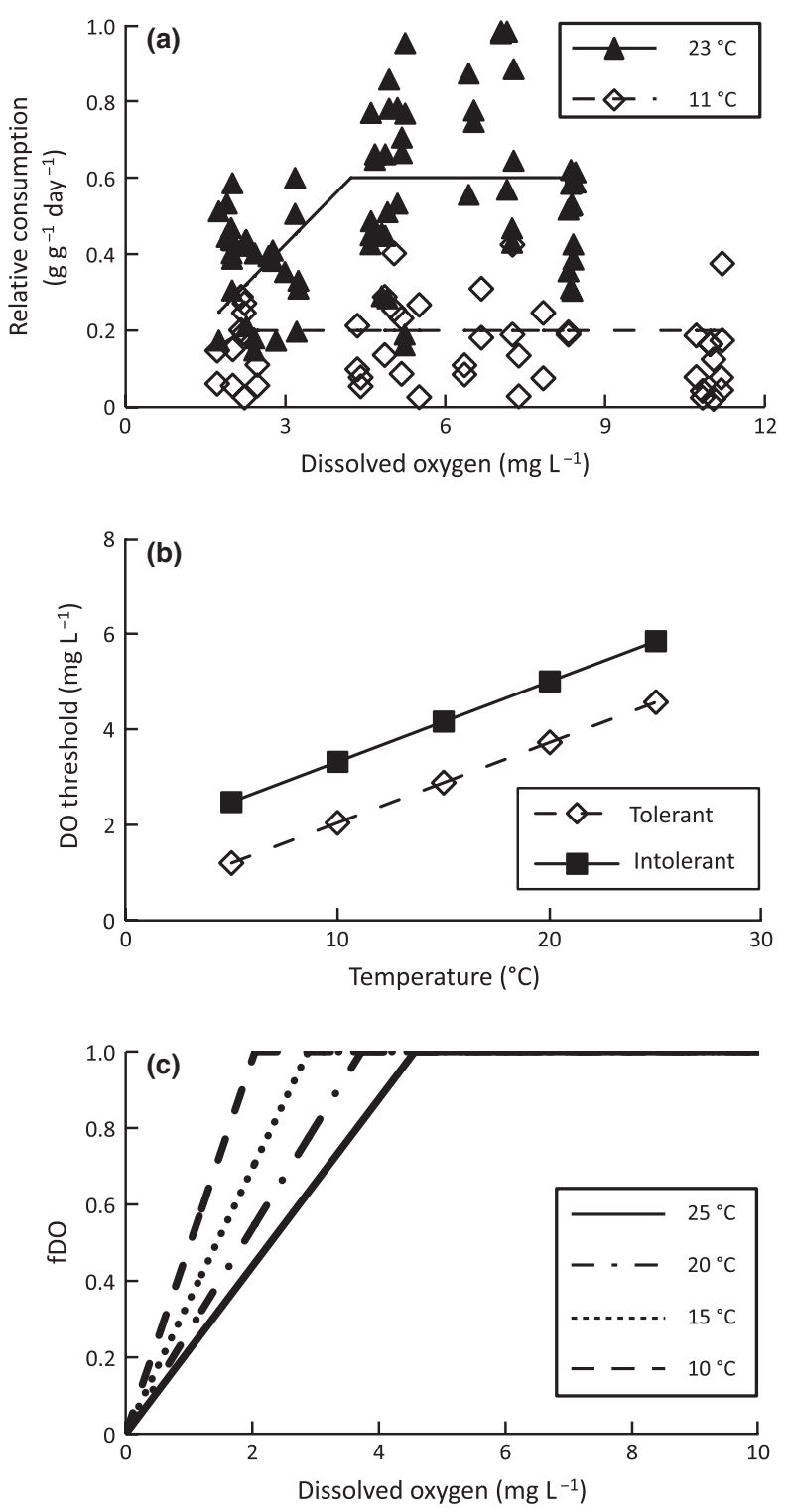

Fig. 1 (a) Relative consumption $\left(\mathrm{g} \mathrm{g}^{-1} \mathrm{~d}^{-1}\right)$ of yellow perch experimentally fed ad libitum at $23{ }^{\circ} \mathrm{C}$ (triangles) and $11^{\circ} \mathrm{C}$ (diamonds) and least residual sums of squares fit to the $23^{\circ} \mathrm{C}$ (solid line) and $11{ }^{\circ} \mathrm{C}$ (dashed line) data; (b) relationship between temperature and the dissolved oxygen (DO) threshold value below which consumption starts to decline for low DO tolerant (diamonds, dashed line) and low DO sensitive (squares, solid line) fish species; (c) relationship between temperature and DO-consumption function demonstrated for four temperatures $\left(25^{\circ} \mathrm{C}=\right.$ solid line; $20^{\circ} \mathrm{C}=$ dotted line; $15^{\circ} \mathrm{C}=$ dot-dashed line; $10{ }^{\circ} \mathrm{C}=$ dashed line).

fDO on a DO threshold of $4.16 \mathrm{mg} \mathrm{L}^{-1}$ reported for salmonids at $15{ }^{\circ} \mathrm{C}$ (sensu Pientka \& Parrish, 2002) (i.e. temperature- $-\mathrm{DO}_{\text {crit }}$ intercept value $=$ $1.63 \mathrm{mg} \mathrm{L}^{-1}$ ) (Fig. 1b).

\section{Habitat model implementation}

Temperature and dissolved oxygen. We used thermal and DO models to characterise depth-specific environmental conditions during 1987-2005. For a full description of these models, see Rucinski et al. (2010). The physical thermal model was based on a 1D version of the Princeton Ocean Model (Blumberg \& Mellor, 1987) developed for Lake Michigan applications (Chen et al., 2002). The model was run from early April to December, which encompasses the growing season for our focal species. The DO model dynamically computed vertical profiles of $\mathrm{DO}$ on an hourly basis and operated at the same spatial scale as the thermal model. These models have been shown to produce a faithful representation of seasonal temperature and DO conditions during 1987-2005 (Rucinski et al., 2010), and thus we used modelderived temperature and $\mathrm{DO}$ outputs as input to our GRP models.

Stratification start and end dates and metalimnion depth were used to characterise simulated temperature patterns between and across years. Stratification start dates were defined as the first day of year (DOY) when the temperature difference between 11 and $21 \mathrm{~m}$ depths exceeded $3{ }^{\circ} \mathrm{C}$. Stratification end dates were defined as the first DOY after DOY 250 when the temperature difference between 11 and $21 \mathrm{~m}$ depths was $<0.05{ }^{\circ} \mathrm{C}$. The temporal duration and depth extent of hypoxia were used to characterise simulated DO patterns between and across years. Hypoxia start dates were defined as the first DOY when DO concentration in at least one depth cell was $<3 \mathrm{mg} \mathrm{L}^{-1}$; end dates were defined as the last DOY with $\mathrm{DO}<3 \mathrm{mg} \mathrm{L}^{-1}$. The annual temporal duration of hypoxia was calculated by subtracting the start date from the end date. The annual depth extent of hypoxia was calculated as the maximum depth above the bottom at which DO levels were less than or equal to $3 \mathrm{mg} \mathrm{L}^{-1}$. Interannual trends in hypoxia temporal duration and depth extent were identified using breakpoint analysis to minimise the residual sum of squares.

Prey availability. We were interested, generally, in how hypoxia influences the access of each fish species or age class to relatively energy-rich benthic invertebrate prey and less energy-rich pelagic zooplankton prey. Data on prey during 1987-2005 were 
lacking; as such, we specified a simplified prey distribution of pelagic, cladoceran (daphnid) zooplankton throughout the upper $22 \mathrm{~m}$ of the water column and benthic chironomids occupying $23-24 \mathrm{~m}$ depths. For simplicity, we allowed fish to forage on either pelagic or benthic prey (determined by water column depth) and assumed that fish were able to forage effectively on each prey type. Chironomids dominate yellow perch diets and are consumed by rainbow smelt under normoxic conditions in central Lake Erie (Pothoven et al., 2009; Roberts et al., 2009), whereas zooplankton are more common prey for both species under hypoxic conditions (Pothoven et al., 2009; Roberts et al., 2009). Cladoceran energy density was $2510 \mathrm{~J} \mathrm{~g} \mathrm{wet}^{-1}$, based on daphnids, and chironomid energy density was $3138 \mathrm{~J} \mathrm{~g} \mathrm{wet}^{-1}$ (Schaeffer et al., 1999). Zooplankton were the only prey available to emerald shiner, because adult and YOY emerald shiner in Lake Erie only rarely consume larval chironomids (Pothoven et al., 2009). Annual species-specific growth and consumption data were not available. Instead, to consider impacts of hypoxia under a range of potential consumption rates, we ran our models with three levels of maximum consumption (proportions of maximum consumption or $P$-values): $0.35,0.50$ and 0.65 . This range of consumption levels spans values considered typical for fishes (Parker-Stetter et al., 2005 and references therein).

Model scenarios. We modelled a $24-\mathrm{m}$ vertical water column, representing the deepest area in Lake Erie's central basin. This site was selected because its environmental conditions are representative of the entire central basin. The water column was divided into 48, 0.5- m-depth intervals (i.e. cells), and GRP estimates were calculated for each 0.5- m-deep cell at daily time steps from April to December, 1987-2005. We estimated GRP for the same-sized individual fish across days and depths for each species and age class under normoxic and hypoxic (i.e. fDO function activated) scenarios. We quantified GRP for a representative adult of each species and for YOY yellow perch and rainbow smelt at each $P$-value. Adult and YOY body mass were based on the mean mass of an individual fish of each species and age class collected from the central basin of Lake Erie in 2005 (S. Pothoven, pers. comm.; T. Höök and S. Ludsin, unpublished data)(Table 1).
Species-specific parameterisation. Species-specific bioenergetics models and parameter values exist for all of our focal species, except emerald shiners. We used previously developed bioenergetics model parameters, when available, with some modifications as described later. For YOY and adult yellow perch, we used well-established Wisconsin bioenergetics model equations and parameter values (Kitchell et al., 1977; Hanson et al., 1997) (Table 1). Rainbow smelt GRP model parameter estimates and equations (Table 1) were from Lantry \& Stewart (1993), with the following exceptions. Lantry \& Stewart (1993) based the upper temperature for consumption (CTM) on field observations and the maximum lethal temperature (CTL; i.e. temperature at which feeding ceases) on field observations from Wismer \& Christie (1987) and Lantry \& Stewart (1993). However, YOY and adult rainbow smelt diet and distribution data in central basin Lake Erie from May to October 2005 indicate that smelt reside and feed at higher temperatures than Lantry and Stewart's values for CTM (adult: $12{ }^{\circ} \mathrm{C}$ ) and CTL (adult: $18{ }^{\circ} \mathrm{C}$ ) (Pothoven et al., 2009; S. Ludsin, unpublished data). For adults only, we increased CTM to $14{ }^{\circ} \mathrm{C}$ and CTL to $20^{\circ} \mathrm{C}$, the latter of which falls within the range of lethal temperatures $\left(19-28.5^{\circ} \mathrm{C}\right.$ ) reported for rainbow smelt (Wismer \& Christie, 1987; Lantry \& Stewart, 1993). Modifying these values accounts for Lake Erie field observations and produces more conservative estimates of hypoxia effects on GRP (i.e. slightly lessens the negative effects of warm temperatures on GRP in oxygenated water above the hypolimnion). Finally, our energy density estimate for rainbow smelt was the mean value for juveniles and adults collected from the central basin of Lake Erie from May to October, 2005 (S. Pothoven, unpublished data). Round goby GRP model equations and parameter values (Table 1) were taken from Lee \& Johnson (2005). Round goby lack a swim bladder, so vertical movement and occupancy of depths more than about two metres above the bottom should increase the activity costs. Therefore, we specified activity values equal to 3.3 for $0-22 \mathrm{~m}$ depths and 1.0 for 23-24 m depths. This higher value is unlikely to overestimate activity costs because it is not even $20 \%$ greater than the activity multiplier of 2.8 , which we calculated from the proportions of standard metabolic rate and active metabolic rate used to estimate round goby mean metabolic rate (Skazkina, 1972, in Charlebois et al., 1997). 
To our knowledge, emerald shiner bioenergetics parameter values have not been derived; thus we combined estimates for other small-bodied, North American cyprinids, fathead minnow (Pimephales promelas Rafinesque) (Duffy, 1998) and dace (Phoxinus spp.) (Hanson et al., 1997, Table 1). We averaged values from these two models for our emerald shiner model, because we expected emerald shiner thermal tolerances to fall between fathead minnows and dace. Mean CTM and upper incipient lethal temperature (UILT) values reported in Wismer \& Christie (1987) for all three fishes fall within $\pm 4{ }^{\circ} \mathrm{C}$ and $\pm 2{ }^{\circ} \mathrm{C}$, respectively. Emerald shiner energy density was calculated as the mean value for adults collected from the central basin of Lake Erie from May to October, 2005 (S. Pothoven, unpublished data; for collection methods, see Pothoven et al., 2009; and Roberts et al., 2009).

\section{Data analysis}

Relative habitat quality and quantity were evaluated by comparing summarised GRP estimates across years. Further, we evaluated the interactive effects of temperature, DO and feeding rate by comparing normoxic and hypoxic scenarios. We generated GRP maps for each scenario, which are annual, colourcoded plots of GRP values for each day $\times$ depth cell. These maps facilitate the visualisation of the spatial and temporal extent of habitat quality. We summarised daily indices by calculating (i) mean daily GRP and (ii) daily number of cells with positive GRP values. To explore the influence of hypoxia on habitat quality for a given year and make comparisons across years, we calculated (i) the difference between mean daily GRP under normoxia and hypoxia and (ii) the per cent change in the daily number of positive cells under hypoxia, compared with normoxia. These annual summaries of hypoxia effects were based on the time period during which hypoxia can occur, specifically DOY 196 (15 July in most years) and DOY 304 (31 October in most years).

To elucidate the relative roles of temperature versus DO in structuring variability in habitat quality, we ran three additional environmental scenarios for adult yellow perch and rainbow smelt at a proportion of maximum consumption of 0.5. First, to evaluate the effect of temperature on interannual habitat quality, we used year-specific daily temperature profiles with a DO profile representing depth-specific mean DO across all years for each date. Second, we used yearspecific DO profiles with a temperature profile representing depth-specific mean temperature across all years for each date. Third, we employed year-specific DO profiles with a uniform (non-stratified) temperature profile (each depth cell for each date equalled the mean temperature across all years, dates, and depths). The second and third scenarios allowed us to evaluate the effect of DO on interannual habitat quality, with and without a temperature-stratified water column. Interannual trends in habitat quality were evaluated using breakpoint analysis.

\section{Results}

Seasonal and interannual trends in stratification and hypoxia

On average, water column stratification developed from 17 May (range: 30 April - 4 June) to 18 October (range: 9-28 October). The onset of stratification did not show any consistent trend from 1987 to 2005 $\left(r^{2}=0.005, P=0.77\right)$. Across years, hypoxic conditions first developed on 21 August (range: 21 July - 23 September) and ended with autumn destratification (range: 9-28 October). During a year of weak hypoxia (e.g. 1996), the temporal duration of hypoxia was 35 days with a depth extent of $5 \mathrm{~m}$ (Fig. 2f). In comparison, during a year of widespread hypoxia (1987), hypoxia lasted 70 days with a depth extent of $8 \mathrm{~m}$ (Fig. 2b). On average, the maximum depth extent of hypoxic waters was $6 \mathrm{~m}$ above the bottom (range: $5-8 \mathrm{~m}$ ). Both the duration and extent of hypoxia decreased from 1987 to 1997 (duration: $r^{2}=0.825$, $P<0.001$; extent: $\left.r^{2}=0.628, P=0.004\right)$ but did not change significantly from 1998 to 2005 (duration: $r^{2}=0.005, P=0.865$; extent: $r^{2}=0.012, P=0.792$ ). These interannual trends in hypoxia do not appear to be strongly related to annual thermal regimes (Rucinski et al., 2010).

\section{Seasonal trends in habitat quality}

For all species except emerald shiner, hypoxia overlapped spatially and seasonally with the otherwise highest quality habitat. For example, during most years under the normoxic scenario, adult yellow perch GRP was highest at 22-24 m depths during early 

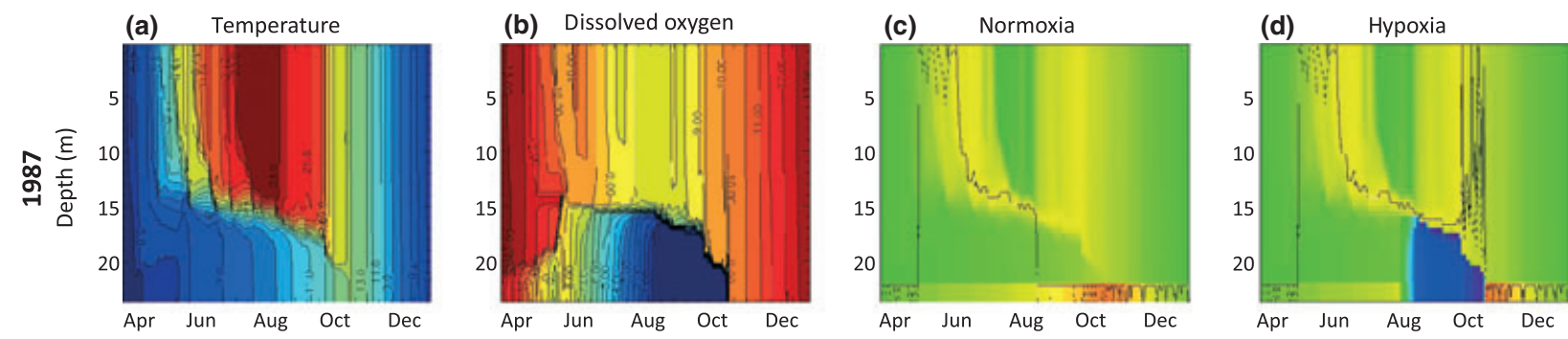

(e)

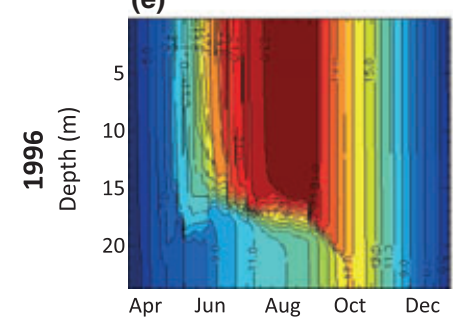

(f)

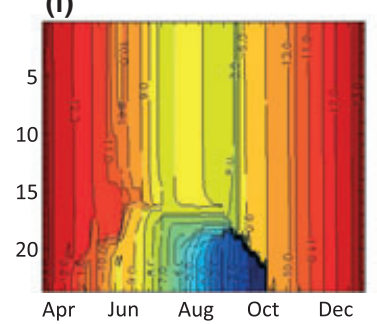

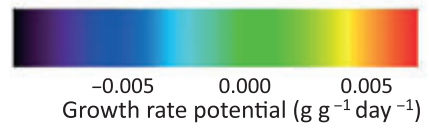

(g)

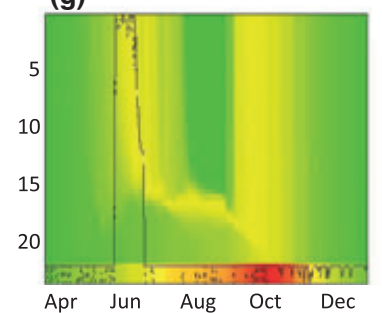

(h)

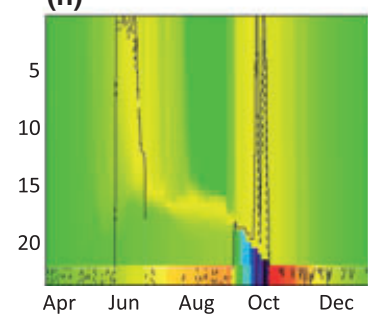

Fig. 2 Contour maps of modelled $(\mathrm{a}, \mathrm{e})$ water temperature $\left({ }^{\circ} \mathrm{C}\right)$ and $(\mathrm{b}, \mathrm{f})$ dissolved oxygen $\left(\mathrm{mg} \mathrm{L}^{-1}\right)$ profiles for a strong (1987) and weak (1996) hypoxia event in central Lake Erie. Adult yellow perch growth rate potential (GRP) maps (proportion of maximum consumption $=0.5$ ) under $(\mathrm{c}, \mathrm{g})$ normoxia (i.e. hypoxia had no influence on modelled consumption) and (d,h) hypoxia (i.e. hypoxiainfluenced consumption). Cells with the maximum GRP on each day fall on and between the solid and dashed lines (i.e. on a given date, the maximum GRP can occur in one or more cells).

October (Fig. 2c,g); under the hypoxic scenario, habitat quality was lowest at these depths during about half of the same time frame (Fig. 2d,h). The effect of hypoxia on habitat quality clearly differed among species and life stages as is evident in GRP maps for 2003 (a year during which hypoxia was intermediate in extent; Fig. 3). For all species and life stages (except YOY yellow perch), epilimnetic GRP values were lower during the summer than other seasons, owing to unfavourably warm temperatures (Fig. 3). Across species, rainbow smelt GRP values were most strongly negatively affected during the hypoxic time period (mean GRP $\pm \mathrm{SE}$ : $-0.0042 \pm 4.0 \times 10^{-4} \mathrm{~g}$ $\mathrm{g}^{-1} \mathrm{~d}^{-1}$ ), owing to a combination of low DO in the hypolimnion and unsuitably warm, epilimnetic temperatures (Fig. 3e). Adult yellow perch habitat quality was less affected by hypoxia (GRP: $0.0021 \pm 5.0 \times$ $10^{-5} \mathrm{~g} \mathrm{~g}^{-1} \mathrm{~d}^{-1}$ ) than that of adult rainbow smelt because of yellow perch's greater tolerance of warm temperatures and low DO (Fig. 3b). Similarly, mean habitat quality of YOY yellow perch (GRP: $0.0056 \pm 1.8 \times 10^{-4} \mathrm{~g} \mathrm{~g}^{-1} \mathrm{~d}^{-1}$ ) and rainbow smelt (GRP: $0.0046 \pm 5.2 \times 10^{-4} \mathrm{~g} \mathrm{~g}^{-1} \mathrm{~d}^{-1}$ ) was less impacted by hypoxia than their adult counterparts
(Fig. 3a,d). Suitable habitat for round goby was generally lacking during periods of hypoxia (GRP: $-0.0063 \pm 1.6 \times 10^{-4} \mathrm{~g} \mathrm{~g}^{-1} \mathrm{~d}^{-1}$; Fig. 3c), owing to the high activity cost of occupying depth cells above $22 \mathrm{~m}$. In contrast, relatively high-quality habitat for growth persisted above the hypolimnion for emerald shiner (GRP: $0.0006 \pm 3.8 \times 10^{-5} \mathrm{~g} \mathrm{~g}^{-1} \mathrm{~d}^{-1}$ ) throughout the season (Fig. 3f), despite emerald shiner being more sensitive to low DO levels than round goby.

\section{Interannual trends in habitat quality}

Strong interannual differences in habitat quality were apparent for all species and life stages (Fig. 4). As expected, annual average habitat quality was lower when hypoxia was permitted to influence consumption when compared to normoxic simulations. Interspecific differences in habitat quality reflect effects of both temperature and DO. To focus on the relative influence of DO on habitat quality, we evaluated the per cent change in habitat quality under the hypoxic versus normoxic scenarios as mean annual per cent change in the number of positive cells (Fig. 4) and GRP across years for each species. Breakpoint

Published 2010. This article is a US Government work and is in the public domain in the USA., Freshwater Biology, 56, 366-383 
(a)
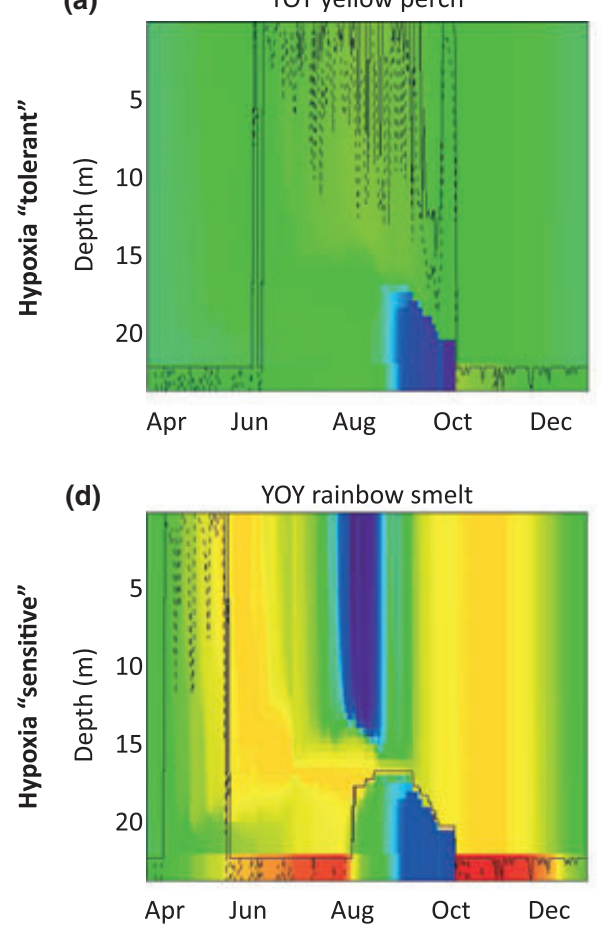

(b)

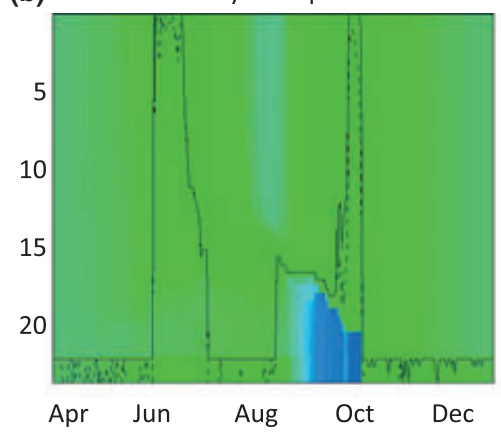

(e) Adult rainbow smelt

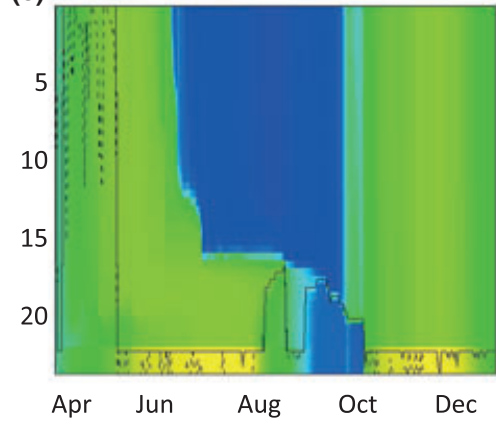

(c)

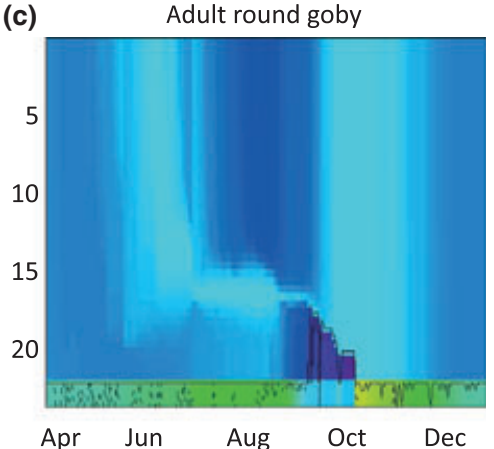

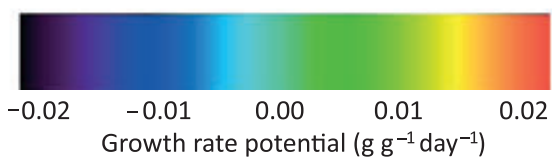

(f) Adult emerald shiner

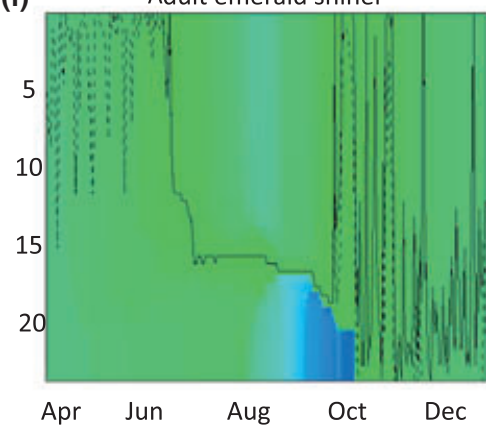

Fig. 3 Modelled growth rate potential (GRP) maps (proportion of maximum consumption $=0.5$ ) for each species and life stage in central Lake Erie during 2003, a year with an intermediate hypoxia event: (a) adult and (b) young-of-year (YOY) yellow perch, (c) adult round goby, (d) adult and (e) YOY rainbow smelt and (f) adult emerald shiner. Hypoxia was permitted to influence consumption in these model simulations. Cells with the maximum GRP on each day fall on and between the solid and dashed lines.

analyses of hypoxia-induced changes in habitat quality suggest that habitat quality for all species and life stages improved from 1987 to 1995 or 1996 and then stabilised (Table 2; Fig. 4). For example, at a consumption level equal to $50 \%$ of maximum consumption, the per cent change in the number of positive GRP cells for adults of each species was significantly more negative in 1987 (yellow perch: $-15.7 \pm 1.3 \%$; rainbow smelt: $-48.5 \pm 4.5 \%$; emerald shiner: $-18.9 \pm$ 1.3; and round goby: $-60.6 \pm 4.7$ ) than in 1996 (yellow perch: $-3.31 \pm 0.6 \%$; rainbow smelt: $-20.9 \pm 0.6 \%$; emerald shiner: $-8.03 \pm 1.3$; and round goby: $-12.8 \pm$ 3.2). Notably, however, temporal trends of habitat quality were somewhat species specific. Interannual trends and variability in habitat quality were less apparent for yellow perch and emerald shiner, because hypoxia has a lesser influence on yellow perch and emerald shiner habitat quality, when compared to rainbow smelt and adult round goby (Fig. 4).

In some cases, temporal trends of habitat quality were highly influenced by feeding rate. For example, the annual per cent change in number of positive cells for adult yellow perch (1987: $-64.2 \pm 4.6)$, rainbow smelt (1987: $-65.7 \pm 4.5)$ and round goby (1987: $-75.3 \pm$ 4.2) was more negative when consumption in the models was set to $35 \%$ of maximum consumption compared to model runs with consumption set to 50 and $65 \%$ of maximum consumption (Fig. 5). On the other hand, a consumption level of $35 \%$ for adult emerald shiner did not provide sufficient energy intake for any cells to support positive GRP values (Fig. 4f). Annual per cent change in the daily number of cells with a positive GRP was similar for model simulations at proportions of maximum consumption of 50 and $65 \%$, for all species but the round goby 

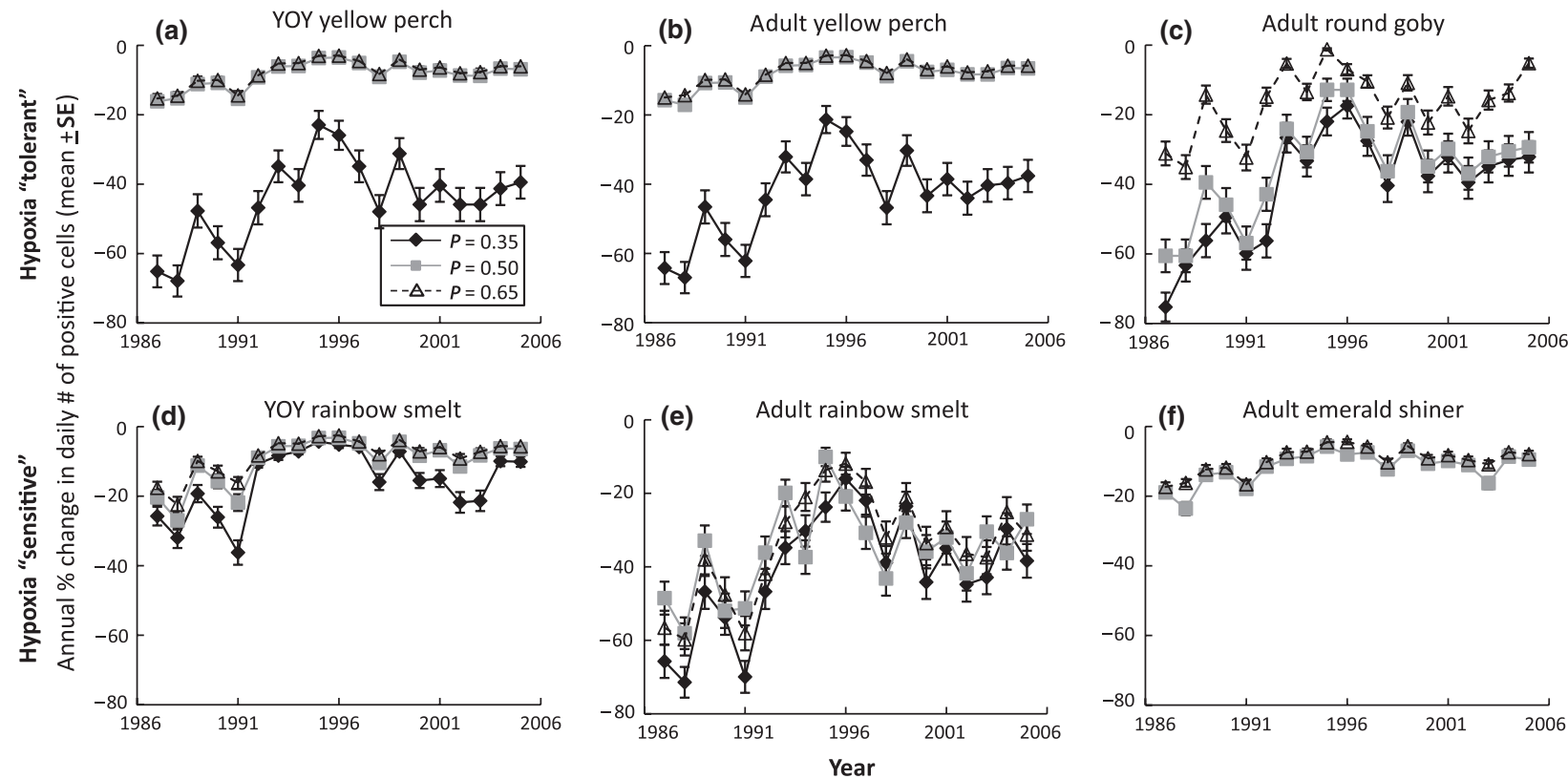

Fig. 4 Annual (1987-2005) per cent change in daily number of cells (mean \pm SE) with a positive growth rate potential (GRP) at three different proportions of maximum consumption $(P)$ values for (a) young-of-year (YOY) yellow perch, (b) adult yellow perch, (c) adult round goby, (d) YOY rainbow smelt, (e) adult rainbow smelt and (f) adult emerald shiner. Solid, black diamonds and solid, black lines represent $P=0.35$; solid, grey squares and solid, grey lines represent $P=0.50$; and open, black triangles and dashed, black lines represent $P=0.65$. Adult emerald shiner do not have a $P=0.35$ line, because no cells were positive throughout the water column under this condition. Annual per cent change is the mean difference in the daily number of positive GRP cells under hypoxia compared with normoxia as a per cent of the number of positive GRP cells under normoxia.

Table 2 Breakpoint analyses of per cent change in two response variables over time (years: 1987-2005) at consumption equal to $50 \%$ of maximum consumption: (1) the per cent change in the number of positive growth rate potential (GRP) cells and (2) the difference in mean GRP under the hypoxic scenario versus normoxic scenario. The breakpoint identifies the year at which the relationship between the response variable and year changes from becoming less negative over time to stabilising. YP: yellow perch; RS: rainbow smelt; RG: round goby; ES: emerald shiner; YOY: young-of-year; d.f.: degrees of freedom; $P$ : level of significance; $R^{2}$ : per cent of variation explained

\begin{tabular}{|c|c|c|c|c|c|c|c|c|}
\hline \multirow[b]{2}{*}{ Species } & \multirow[b]{2}{*}{ Life stage } & \multirow[b]{2}{*}{ Breakpoint (year) } & \multicolumn{3}{|c|}{1987 - breakpoint year } & \multicolumn{3}{|c|}{ Breakpoint year $+1-2005$} \\
\hline & & & d.f. & $P$ & $R^{2}$ & d.f. & $P$ & $R^{2}$ \\
\hline \multicolumn{9}{|c|}{ (1) $\%$ change in \# positive GRP cells } \\
\hline \multirow[t]{2}{*}{ YP } & Adult & 1996 & 9 & $<0.001$ & 0.84 & 8 & 0.530 & 0.06 \\
\hline & YOY & 1996 & 9 & $<0.001$ & 0.84 & 8 & 0.498 & 0.07 \\
\hline \multirow[t]{2}{*}{ RS } & Adult & 1996 & 9 & 0.009 & 0.60 & 8 & 0.612 & 0.04 \\
\hline & YOY & 1995 & 8 & 0.006 & 0.68 & 9 & 0.344 & 0.11 \\
\hline RG & Adult & 1996 & 9 & $<0.001$ & 0.80 & 8 & 0.546 & 0.05 \\
\hline ES & Adult & 1995 & 8 & 0.002 & 0.76 & 9 & 0.316 & 0.12 \\
\hline \multicolumn{9}{|c|}{ (2) Difference in GRP } \\
\hline \multirow[t]{2}{*}{ YP } & Adult & $\mathrm{n} / \mathrm{a}$ & 18 & 0.032 & 0.24 & $\mathrm{n} / \mathrm{a}$ & $\mathrm{n} / \mathrm{a}$ & $\mathrm{n} / \mathrm{a}$ \\
\hline & YOY & 1996 & 9 & $<0.001$ & 0.77 & 8 & 0.99 & $2.1 \times 10^{-5}$ \\
\hline \multirow[t]{2}{*}{ RS } & Adult & 1995 & 8 & 0.003 & 0.74 & 9 & 0.02 & 0.50 \\
\hline & YOY & 1996 & 9 & $<0.001$ & 0.83 & 8 & 0.612 & 0.04 \\
\hline RG & Adult & 1996 & 9 & $<0.001$ & 0.84 & 8 & 0.264 & 0.17 \\
\hline ES & Adult & 1996 & 9 & $<0.001$ & 0.76 & 8 & 0.98 & $7.5 \times 10^{-5}$ \\
\hline
\end{tabular}

(Fig. 4c). At these higher feeding levels, adult rainbow smelt and adult round goby habitat quality was more negatively affected by hypoxia than that of other species (Fig. 4). In contrast to per cent change in number of positive GRP cells, the annual mean difference between GRP under the normoxic and

Published 2010. This article is a US Government work and is in the public domain in the USA., Freshwater Biology, 56, 366-383 

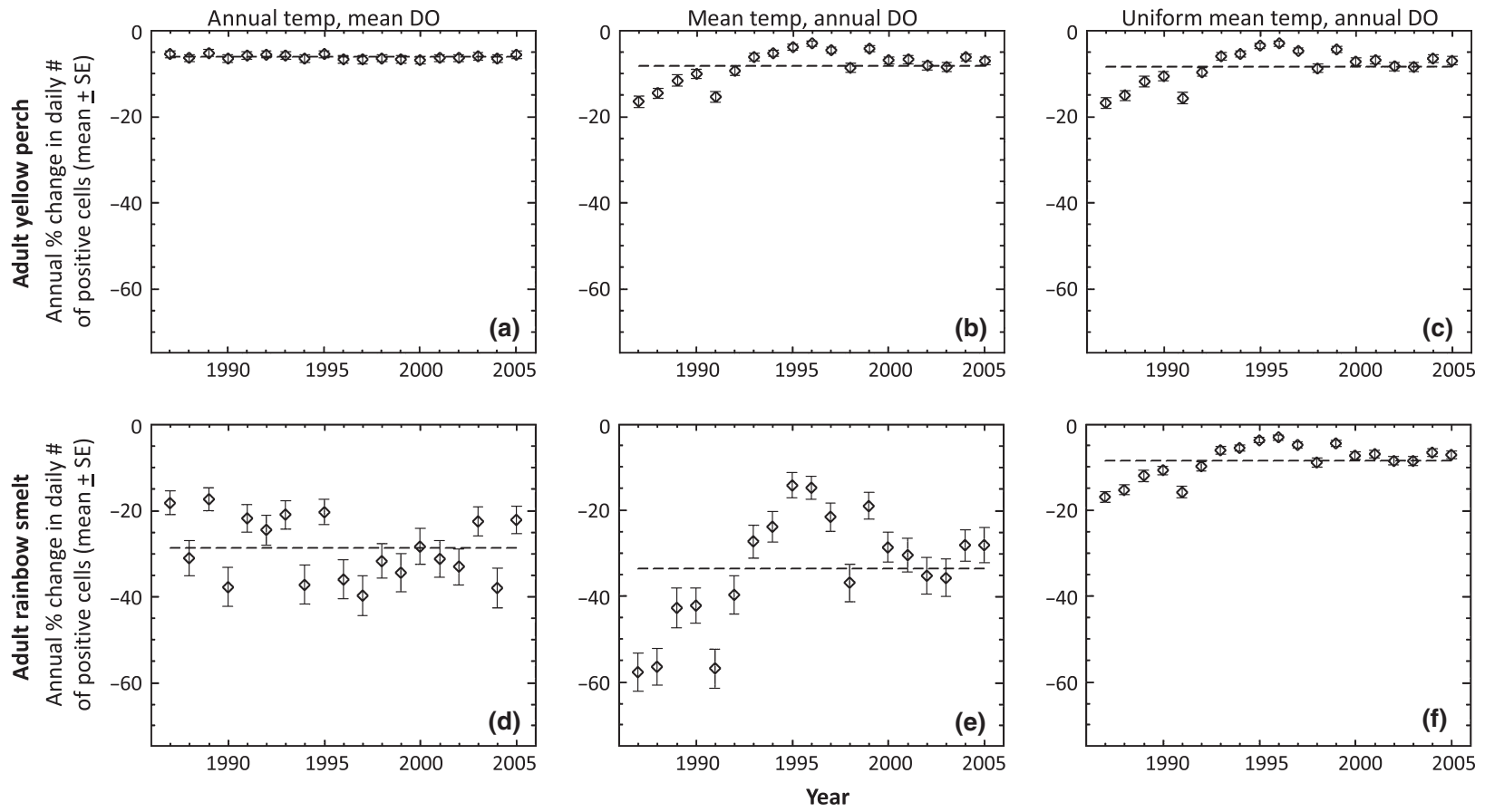

Fig. 5 Annual (1987-2005) mean $( \pm$ SE) per cent change in the daily number of cells with positive growth rate potential between normoxic (i.e. hypoxia was not permitted to influence consumption) and hypoxic (i.e. hypoxia was permitted to influence consumption) scenarios for adult yellow perch $(\mathrm{a}-\mathrm{c})$ and rainbow smelt $(\mathrm{d}-\mathrm{f})$ in central Lake Erie. Proportion of maximum consumption was set to 0.5 in these simulations. Temperature and dissolved oxygen conditions were applied as follows: (a,d) annual temperature profiles but mean (1987-2005) depth- and date-specific DO profile; (b,e) annual DO profiles but mean (1987-2005) depth- and datespecific temperature profile; $(\mathrm{c}, \mathrm{f})$ ) annual DO profiles but uniform (i.e. non-stratified; average of all years, dates and depths) temperature. Horizontal dashed lines represent means across all years.

hypoxic scenarios was greatest for model simulations in which consumption level equalled $65 \%$ of maximum consumption (e.g. adult rainbow smelt: $-3.8 \times$ $\left.10^{-3} \pm 1.1 \times 10^{-4}\right)$, followed by consumption equal to $50 \%\left(-2.9 \times 10^{-3} \pm 8.8 \times 10^{-5}\right)$ and $35 \%\left(-2.0 \times 10^{-3} \pm\right.$ $6.1 \times 10^{-5}$ ) of maximum consumption. Thus, when potential consumption rates are low (e.g. $35 \%$ of maximum consumption), hypoxia can only further reduce consumption a slight amount; in contrast, when potential consumption rates are high, hypoxia can have a strong impact on habitat quality. For example, the difference between adult rainbow smelt mean GRP under the hypoxic and the normoxic scenarios at $65 \%$ of maximum consumption is almost twice as large as that at $35 \%$ of maximum consumption.

We executed additional scenarios for adult yellow perch and rainbow smelt to further elucidate the relative roles of temperature versus $\mathrm{DO}$ availability in regulating variability in habitat quality. These analyses indicate that the relative effects of temperature versus DO on habitat quality are species specific, depending primarily on temperature tolerances. Yellow perch habitat quality was more strongly influenced by interannual changes in $\mathrm{DO}$, when compared to interannual changes in temperature. Interannual variability in the per cent change in the number of positive GRP cells for yellow perch was greater when DO varies with year and temperature does not (Fig. $5 b, c)$ than when temperature varies with year and DO does not (Fig. 5a). In contrast, adult rainbow smelt habitat quality was more strongly influenced by stratified temperature profiles (Fig. $5 \mathrm{~d}, \mathrm{e}$ ), particularly when combined with interannual variability in DO (Fig. 5e) than by interannual variability in DO under uniform temperature conditions (Fig. 5f). Therefore, warm epilimnetic water temperatures in a stratified water column have a greater effect on rainbow smelt habitat quality and variability than does DO availability alone; however, the interactive effects of a temperature-stratified water column and hypoxia on adult rainbow smelt habitat quality are greatest. 


\section{Discussion}

Analyses of GRP modelling results from 1987 to 2005 demonstrate seasonal and interannual effects of hypoxia on habitat quality across multiple fish species and age classes. Seasonally, hypoxia reduces hypolimnetic habitat quality for approximately 3 months, from mid-July to mid-October. Among fishes, the relative effect of hypoxia on habitat quality depends on the interaction between each species' tolerance to low, hypolimnetic DO levels and warm, epilimnetic water temperatures. Temporal trends (1987-2005) of hypoxia-influenced habitat quality reflect a reduction in the extent and duration of hypoxia from 1987 to 1996, in response to reduced cultural eutrophication during this time period, followed by more stable conditions from 1997 to 2005. Seasonal hypoxia can affect fish growth, reproduction and behaviour and thereby affect population dynamics and community composition.

In central Lake Erie, hypoxia-induced reduction in hypolimnetic habitat quality occurred in mid- to late summer and lasted for up to 90 days. This time period overlaps seasonally with relatively high benthic habitat quality for fishes that prey upon chironomids and other benthic invertebrates (e.g. yellow perch, rainbow smelt and round goby). The overlap between hypoxia and otherwise high-quality hypolimnetic habitat also occurs when many fish species might maximise either somatic growth or lipid storage in anticipation of low food intake and gonadal growth during winter (Tanasichuk \& Mackay, 1989; Henderson, Trivedi \& Collins, 2000). Reduced juvenile fish growth and energy accumulation during late summer and early autumn could result in greater overwinter mortality because of resulting low energy stores, higher mass-specific respiration rates and greater susceptibility to predators and environmental extremes (Post \& Evans, 1989; Sogard, 1997). Indeed, such sizeselective overwinter mortality has been demonstrated for a variety of species, including juvenile yellow perch (Post \& Evans, 1989). In a modelling study of juvenile fish growth among estuaries, Miller et al. (2000) concluded that juvenile fish performance during summer was highly dependent on maximum temperatures and minimum DO levels, with differences in these abiotic factors resulting in large $(3 x)$ variation in fish growth among estuaries. Thus, the interactive effects of temperature and DO could influence under- yearling growth and survival and thereby lead to population-level consequences.

Hypoxia can have a number of potential effects on reproductive success, fecundity, egg characteristics and hatch success (Wu, 2002; Pollock et al., 2007). For multiple fish species, chronic exposure to hypoxia has been shown to negatively affect various aspects of male and female reproductive success (gonadal development and maturation, sperm motility, fertilisation success, hatching rate and larval survival), most likely by acting as an endocrine disruptor ( $\mathrm{Wu}$ et al., 2003; Thomas et al., 2007; Thomas \& Rahman, 2009). However, reproductive effects when fish are displaced by low oxygen (e.g. when hypoxic conditions force the occupation of thermally inferior habitats) are unclear. More research is needed to determine whether late summer hypoxia affects gonadal development and egg quality of fishes that develop ovaries during winter and spawn in the spring, such as rainbow smelt and yellow perch.

The extent to which temperature and DO interact to affect habitat quality and lead to population-level consequences may depend in part on behavioural dynamics of individual fish. For instance, hypoxia may not eliminate the access to hypolimnetic habitat. In fact, foraging forays into hypoxic waters have been observed for both bay anchovy (Anchoa mitchilli Valenciennes) in the Chesapeake Bay (Taylor et al., 2007) and yellow perch in central Lake Erie (Roberts, 2010). Even if some fish access benthic prey via forays, this could be a relatively energetically expensive feeding strategy (Taylor et al., 2007). Furthermore, fish would still spend the majority of their time higher in the water column and thus be more likely to consume pelagic prey and, for some species, be exposed to suboptimally warm water temperatures. For example, rainbow smelt appear to experience a thermal-DO squeeze (sensu Coutant, 1985) during hypoxia owing to the combination of low tolerance to both hypoxia and warm water temperatures. Therefore, energy gained from the capture and consumption of higher quality prey via hypolimnetic foraging forays is unlikely to counterbalance the physiological costs of occupying warmer metalimnetic water. In contrast cool-water and warm-water species, such as yellow perch, may benefit from foraging forays, if the energy gained from capturing and consuming benthic prey is greater than the energy spent during the foray. 
The development of hypolimnetic hypoxia may also cause several fishes to move horizontally into shallower, coastal habitats. Field surveys in central Lake Erie suggest that such hypoxia-induced horizontal migrations do in fact take place (Vanderploeg et al., 2009). During 2005, round goby were largely absent from hypoxic areas of Lake Erie's central basin, most likely having migrated horizontally to shallower, oxygenated coastal habitat (T. Höök, pers. observ.). Although some adult rainbow smelt may also migrate horizontally, at least a portion of them move vertically into the metalimnion (Pothoven et al., 2009; Vanderploeg et al., 2009). Studies in other systems indicate that crowding in normoxic areas can potentially increase inter- and intraspecific competition for prey (Eby et al., 2005). Our results indicate that hypoxia had a stronger, negative effect on habitat quality under low, but still reasonable, levels of consumption, particularly for yellow perch. Hence, reduced energy intake because of competition could exacerbate habitat quality reduction under hypoxia for some species. In contrast, piscivores could benefit from the concentration of prey species in shallower waters during hypoxia. For example, Costantini et al. (2008) found that striped bass (Morone saxatilis Walbaum) predation efficiency might improve during hypolimnetic hypoxia in Chesapeake Bay, because of the enhanced prey fish availability in shallow, oxygenated waters. Similarly, walleye in central Lake Erie might benefit from the concentration of prey fishes in epi- and metalimnetic waters during hypoxia (S. B. Brandt, pers. comm.).

Interannual patterns in habitat quality across species mirror trends in the extent and duration of hypoxia in the central basin as simulated by the 1D thermal and DO models. In response to improved water quality (i.e. reduced phosphorus loading to Lake Erie), relative habitat quality increased between 1987 and 1995 or 1996. After a peak in 1996, relative habitat quality across species and life stages stabilised, with some oscillation, around the 19-year means. Among species, the effect of hypoxia on annual habitat quality was more pronounced for cold-water species and highly benthic species. For example, rainbow smelt habitat quality is constrained by warm-epilimnetic water temperatures, whereas round goby habitat quality is constrained by the energy required to maintain a higher position in the water column. At sufficiently high feeding rates $(P=0.50$ and 0.65 ), the effect of hypoxia on habitat quality was less dramatic and similar for cool- and warm-water species (e.g. yellow perch and emerald shiner) that can tolerate warmer temperatures and therefore have a greater amount of suitable habitat remaining during hypoxia. For example, adult yellow perch relative habitat quality was affected by DO conditions regardless of whether the water column was stratified or uniform (i.e. most non-hypolimnetic habitat was suitable for adult yellow perch). Thus, the degree to which interannual variability in temperature versus DO profiles contributed to variability in habitat quality differed among species. As such, knowledge of fish thermal guilds and sensitivity to hypoxia is important when exploring the effects of hypoxia on relative fish habitat quality and quantity.

Our simulations of four fish species and two age classes over 19 years suggest that sublethal effects of hypoxia on fish habitat quality can have important implications for the performance of individual fish species and age classes. Differences among species in their sensitivity to low DO and temperature regimes along with other factors that influence water column distribution result in differential effects on habitat quality and, ultimately, can be expected to differentially affect population performance and fish community composition. For example, cultural eutrophication of Lake Erie led to declines of sensitive, cold-water fish species during the mid-20th century (Ludsin et al., 2001). In turn, central Lake Erie fish species richness increased between 1970 and 1996 because of the recovery of hypoxia-sensitive, benthivorous fishes (e.g. lake whitefish, smallmouth bass and burbot, Lota lota Linnaeus), probably due in large part to a decrease in hypolimnetic hypoxia with reduced phosphorus loading (Ludsin et al., 2001). The recovery of these fishes demonstrates how differential performance among species can lead to important changes in the fish community. More subtle effects on population performance are, however, likely to occur before severe population declines. For example, rainbow smelt and round goby, both introduced species, probably suffer reduced performance in central Lake Erie in response to hypoxia.

This study serves as a starting point for evaluating how hypoxia impacted past fish communities in the central basin of Lake Erie, with the ultimate goal of forecasting how fish habitat quality will be affected by human- and climate-induced changes to chemical and 
physical conditions, such as nutrient loading and stratification. Elucidating how fish species and guilds are interactively affected by temperature and hypoxia should facilitate the prediction of species-specific responses to future hypoxia events, particularly under novel climatic conditions. For example, climate change is predicted to result in warmer surface water temperatures and longer stratification periods across the Great Lakes (Trumpickas, Shuter \& Minns, 2009). Longer stratification periods could increase the temporal and/or spatial extent of hypolimnetic hypoxia (Trumpickas et al., 2009) and, consequently, lead to poor quality fish habitat. Larger hypoxia events in combination with warmer surface water temperatures can be expected to intensify the thermal-DO squeeze experienced by cold-water species, such as rainbow smelt, in both space and time.

\section{Acknowledgments}

This research was funded by United States National Oceanic and Atmospheric Administration (NOAA) Center for Sponsored Coastal Ocean Research, Coastal Ocean Program grant NA07OAR432000. This paper is NOAA EcoFore-Lake Erie Project contribution \# 09-005. This is NOAA-GLERL contribution \# 1572.

\section{References}

Aku P.M.K. \& Tonn W.M. (1999) Effects of hypolimnetic oxygenation on the food resources and feeding ecology of cisco in Amisk Lake, Alberta. Transactions of the American Fisheries Society, 128, 17-30.

Blumberg A. \& Mellor G. (1987) A description of a threedimensional coastal ocean circulation model. In: Three Dimensional Ocean Models, Coastal and Estuarine Sciences (Ed. N.S. Heaps), pp. 1-16. American Geophysical Union, Washington, DC.

Brandt S.B., Magnuson J.J. \& Crowder L.B. (1980) Thermal habitat partitioning by fishes in Lake Michigan. Canadian Journal of Fisheries and Aquatic Sciences, 37, 1557-1564.

Brandt S.B., Mason D.M. \& Patrick E.V. (1992) Spatially explicit models of fish growth rate. Fisheries, 17, 23.

Brandt S.B., Gerkin M., Hartman K.J. \& Demers E. (2009) Effects of hypoxia on food consumption and growth of juvenile striped bass (Morone saxatilis). Journal of Experimental Marine Biology and Ecology, 381(Suppl. 1), S143-S149.
Breitburg D.L. (2002) Effects of hypoxia, and the balance between hypoxia and enrichment, on coastal fishes and fisheries. Estuaries, 25, 767-781.

Breitburg D.L., Loher T., Pacey C.A. \& Gerstein A. (1997) Varying effects of low dissolved oxygen on trophic interactions in an estuarine food web. Ecological Monographs, 67, 489-507.

Breitburg D.L., Adamack A., Rose K.A., Kolesar S.E., Decker B., Purcell J.E., Keister J.E. \& Cowan J.H. (2003) The pattern and influence of low dissolved oxygen in the Patuxent River, a seasonally hypoxic estuary. Estuaries, 26, 280-297.

Burleson M.L., Wilhelm D.R. \& Smatresk N.J. (2001) The influence of fish size on the avoidance of hypoxia and oxygen selection by largemouth bass. Journal of Fish Biology, 59, 1336-1349.

Burns N.M., Rockwell D.C., Bertram P.E., Dolan D.M. \& Ciborowski J.J.H. (2005) Trends in temperature, secchi depth, and dissolved oxygen depletion rates in the central basin of Lake Erie, 1983-2002. Journal of Great Lakes Research 31(Suppl. 2), 35-49.

Cerezo J. \& Garcia Garcia B. (2004) The effects of oxygen levels on oxygen consumption, survival and ventilatory frequency of sharpsnout sea bream (Diplodus puntazzo Gmelin, 1789) at different conditions of temperature and fish weight. Journal of Applied Ichthyology, 20, 488-492.

Chabot D. \& Dutil J.D. (1999) Reduced growth of Atlantic cod in non-lethal hypoxic conditions. Journal of Fish Biology, 55, 472-491.

Charlebois P.M., Marsden J.E., Goettel R.G., Wolfe R.K., Jude D.J. \& Rudnika S. (1997) The Round Goby, Neogobius melanostomus (Pallas), a Review of European and North American Literature. Illinois-Indiana Sea Grant Program and Illinois Natural History Survey, Champaign, IL, INHS Special Publication No. 20: 76.

Chen C., Ji R., Schwab D.J. et al. (2002) A model study of the coupled biological and physical dynamics in Lake Michigan. Ecological Modeling, 152, 145-168.

Claireaux G., Webber D.M., Lagardere J.P. \& Kerr S.R. (2000) Influence of water temperature and oxygenation on the aerobic metabolic scope of Atlantic cod (Gadus morhua). Journal of Sea Research, 44, 257-265.

Costantini M., Ludsin S.A., Mason D.M., Zhang X.S., Boicourt W.C. \& Brandt S.B. (2008) Effect of hypoxia on habitat quality of striped bass (Morone saxatilis) in Chesapeake Bay. Canadian Journal of Fisheries and Aquatic Sciences, 65, 989-1002.

Coutant C.C. (1977) Compilation of temperature preference data. Journal of the Fisheries Research Board of Canada, 34, 739-745.

Coutant C.C. (1985) Striped bass, temperature, and dissolved-oxygen - a speculative hypothesis for

Published 2010. This article is a US Government work and is in the public domain in the USA., Freshwater Biology, 56, 366-383 
environmental risk. Transactions of the American Fisheries Society, 114, 31-61.

Coutant C.C. (1990) Temperature-oxygen habitat for fresh-water and coastal striped bass in a changing climate. Transactions of the American Fisheries Society, 119, 240-253.

Diaz R.J. \& Rosenberg R. (2008) Spreading dead zones and consequences for marine ecosystems. Science, 321, 926-929.

Dolan D.M. (1993) Point source loadings of phosphorus to Lake Erie: 1986-1990. Journal of Great Lakes Research, 19, 212-223.

Duffy W.G. (1998) Population dynamics, production, and prey consumption of fathead minnows (Pimephales promelas) in prairie wetlands: a bioenergetics approach. Canadian Journal of Fisheries and Aquatic Sciences, 55, 15-27.

Eby L.A., Crowder L.B., Mcclellan C.M., Peterson C.H. \& Powers M.J. (2005) Habitat degradation from intermittent hypoxia: impacts on demersal fishes. Marine Ecology Progress Series, 291, 249-261.

Fang X., Stefan H.G., Eaton J.G., Mccormick J.H. \& Alam S.R. (2004) Simulation of thermal/dissolved oxygen habitat for fishes in lakes under different climate scenarios. Part 1. Cool-water fish in the contiguous U.S. Ecological Modeling, 172, 13-37.

Fitzgibbon Q.P., Strawbridge A. \& Seymour R.S. (2007) Metabolic scope, swimming performance and the effects of hypoxia in the mulloway, Argyrosomus japonicus (Pisces : Sciaenidae). Aquaculture, 270, 358368.

Gray J.S., Wu R.S.S. \& Or Y.Y. (2002) Effects of hypoxia and organic enrichment on the coastal marine environment. Marine Ecology Progress Series, 238, 249-279.

Hanson P.C., Johnson T.B., Schindler D.E. \& Kitchell J.F. (1997) Fish Bioenergetics 3.0. University of WisconsinMadison Center for Limnology and University of Wisconsin Sea Grant Institute, Madison, WI.

Hawley N., Johengen T.H., Rao Y.R., Ruberg S.A., Beletsky D., Ludsin S.A., Eadie B.H., Schwab D.J., Croley T.E. \& Brandt S.B. (2006) Lake Erie hypoxia prompts Canada-U.S. study. EOS, Transactions, American Geophysical Union, 87, 313-315.

Henderson B.A., Trivedi T. \& Collins N. (2000) Annual cycle of energy allocation to growth and reproduction of yellow perch. Journal of Fish Biology, 57, 122-133.

Höök T.O., Rutherford E.S., Mason D.M. \& Carter G.S. (2007) Hatch dates, growth rates, survival and overwinter mortality of age- 0 alewives in Lake Michigan: implications for habitat-specific recruitment success. Transactions of the American Fisheries Society, 136, 12981312.
Horppila J., Malinen T., Nurminen L., Tallberg P. \& Vinni M. (2000) A metalimnetic oxygen minimum indirectly contributing to the low biomass of cladocerans in Lake Hiidenvesi - a diurnal study on the refuge effect. Hydrobiologia, 436, 81-90.

Jordan A.D. \& Steffensen J.F. (2007) Effects of ration size and hypoxia on specific dynamic action in the cod. Physiological and Biochemical Zoology, 80, 178-185.

Kennish M.J. (2002) Environmental threats and environmental future of estuaries. Environmental Conservation, 29, 78-108.

Kitchell J.F., Stewart D.J. \& Weininger D. (1977) Applications of a bioenergetics model to yellow perch (Perca flavescens) and walleye (Stizostedion vitreum vitreum). Journal of the Fisheries Research Board of Canada, 34, 1922-1935.

Kling G.W., Hayhoe K., Johnson L.B. et al. (2003) Confronting climate change in the Great Lakes region: impacts on our communities and ecosystems. Union of Concerned Scientists, Cambridge, MA. Ecological Society of America, Washington, D.C., p. 105.

Lantry B.F. \& Stewart D.J. (1993) Ecological energetics of rainbow smelt in the Laurentian Great Lakes: an interlake comparison. Transactions of the American Fisheries Society, 122, 951-976.

Lee V.A. \& Johnson T.B. (2005) Development of a bioenergetics model for the round goby (Neogobius melanostomus). Journal of Great Lakes Research, 31, 125134.

Ludsin S.A., Kershner M.W., Blocksom K.A., Knight R.L. \& Stein R.A. (2001) Life after death in Lake Erie: nutrient controls drive fish species richness, rehabilitation. Ecological Applications, 11, 731-746.

Ludsin S.A., Zhang X., Brandt S.B., Roman M.R., Boicourt W.C., Mason D.M. \& Constantini M. (2009) Hypoxiaavoidance by planktivorous fish in Chesapeake Bay: implications for food web interactions and fish recruitment. Journal of Experimental Marine Biology and Ecology, 381(Suppl. 1), S121-S131.

Magnuson J.J., Crowder L.B. \& Medvick P.A. (1979) Temperature as an ecological resource. American Zoologist, 19, 331-343.

Mason D.M. \& Patrick E.V. (1993) A model for the spacetime dependence of feeding for pelagic fish populations. Transactions of the American Fisheries Society, 122, 884-901.

Matisoff G. \& Ciborowski J.J.H. (2005) Lake Erie trophic status collaborative study. Journal of Great Lakes Research, 31(Suppl. 2), 1-10.

Matthews W.J. \& Maness J.D. (1979) Critical thermal maxima, oxygen tolerances and success of cyprinid fishes in a southwestern river. American Midland Naturalist, 102, 374-377.

Published 2010. This article is a US Government work and is in the public domain in the USA., Freshwater Biology, 56, 366-383 
Miller J.M., Neill W.H., Duchon K.A. \& Ross S.W. (2000) Ecophysiological determinants of secondary production in salt marshes: a simulation study. in: Concepts and Controversies in Tidal Marsh Ecology (Eds M.P. Weinstein \& D.A. Kreeger), pp. 315-331. Springer, Netherlands.

Parker-Stetter S.L., Witzel L.D., Rudstam L.G., Einhouse D.W. \& Mills E.L. (2005) Energetic consequences of diet shifts in Lake Erie rainbow smelt (Osmerus mordax). Canadian Journal of Fisheries and Aquatic Sciences, 62, 145-152.

Pichavant K., Person-Le-Ruyet J., Le Bayon N., Severe A., Le Roux A., Quemener L., Maxime V., Nonnotte G. \& Boeuf G. (2000) Effects of hypoxia on growth and metabolism of juvenile turbot. Aquaculture, 188, 103114.

Pientka B. \& Parrish D.L. (2002) Habitat selection of predator and prey: atlantic salmon and rainbow smelt overlap, based on temperature and dissolved oxygen. Transactions of the American Fisheries Society, 131, 11801193.

Pihl L., Baden S.P., Diaz R.J. \& Schaffner L.C. (1992) Hypoxia-induced structural changes in the diet of bottom-feeding fish and crustacea. Marine Biology, 112, 349-361.

Pollock M.S., Clarke L.M.J. \& Dube M.G. (2007) The effects of hypoxia on fishes: from ecological relevance to physiological effects. Environmental Reviews, 15, 114.

Post J.R. \& Evans D.O. (1989) Size dependent overwinter mortality of young-of-the-year yellow perch (Perca flavescens) - laboratory, in situ enclosure, and field experiments. Canadian Journal of Fisheries and Aquatic Sciences, 46, 1958-1968.

Pothoven S.A., Vanderploeg H.A., Ludsin S.A., Höök T.O. \& Brandt S.B. (2009) Feeding ecology of emerald shiners and rainbow smelt in central Lake Erie. Journal of Great Lakes Research, 35, 190-198.

Prince E.D. \& Goodyear C.P. (2006) Hypoxia-based habitat compression of tropical pelagic fishes. Fisheries Oceanography, 15, 451-464.

Rao Y.R., Hawley N., Charlton M.N. \& Schertzer W.M. (2008) Physical processes and hypoxia in the central basin of Lake Erie. Limnology and Oceanography, 53, 2007-2020.

Reynolds W.W. \& Casterlin M.E. (1978) Ontogenetic change in preferred temperature and diel activity of the yellow bullhead, Ictaluris natalis. Comparative Biochemistry and Physiology Part A: Physiology, 59, 409-411.

Reynoldson T.B. \& Hamilton A.L. (1993) Historic Changes in Populations of Burrowing Mayflies (Hexagenia limbata) from Lake Erie Based on Sediment Tusk Profiles. Journal of Great Lakes Research, 19, 250-257.
Robb T. \& Abrahams M.V. (2003) Variation in tolerance to hypoxia in a predator and prey species: an ecological advantage of being small? Journal of Fish Biology, 62, 1067-1081.

Roberts J.J. (2010) The ecological consequences of hypoxia for yellow perch (Perca flavescens) in Lake Erie. PhD Dissertation, University of Michigan, Ann Arbor.

Roberts J.J., Höök T.O., Ludsin S.A., Pothoven S.A., Vanderploeg H.A. \& Brandt S.B. (2009) Effects of hypolimnetic hypoxia on foraging and distributions of Lake Erie yellow perch. Journal of Experimental Marine Biology and Ecology, 381(Suppl. 1), S132-S142.

Rucinski D.K., Beletsky D., Depinto J.V., Schwab D.J. \& Scavia D. (2010) A simple 1-dimensional, climate based dissolved oxygen model for the central basin of Lake Erie. Journal of Great Lakes Research, 36, 465-476.

Schaeffer J.S., Haas R.C., Diana J.S. \& Breck J.E. (1999) Field test of two energetic models for yellow perch. Transactions of the American Fisheries Society, 128, 414435.

Schurmann H. \& Steffensen J.F. (1997) Effects of temperature, hypoxia and activity on the metabolism of juvenile Atlantic cod. Journal of Fish Biology, 50, 11661180.

Shimps E.L., Rice J.A. \& Osborne J.A. (2005) Hypoxia tolerance in two juvenile estuary-dependent fishes. Journal of Experimental Marine Biology and Ecology, 325, 146-162.

Smale M.A. \& Rabeni C.F. (1995) Hypoxia and hyperthermia tolerances of headwater stream fishes. Transactions of the American Fisheries Society, 124, 698-710.

Sogard S.M. (1997) Size-selective mortality in the juvenile stage of teleost fishes: a review. Bulletin of Marine Science, 60, 1129-1157.

Stierhoff K.L., Targett T.E. \& Miller K. (2006) Ecophysiological responses of juvenile summer and winter flounder to hypoxia: experimental and modeling analyses of effects on estuarine nursery quality. Marine Ecology Progress Series, 325, 255-266.

Tanasichuk R.W. \& Mackay W.C. (1989) Quantitative and qualitative characteristics of somatic and gonadal growth of yellow perch (Perca flavescens) from Lac Ste. Anne, Alberta. Canadian Journal of Fisheries and Aquatic Sciences, 46, 989-994.

Taylor J.C., Rand P.S. \& Jenkins J. (2007) Swimming behavior of juvenile anchovies (Anchoa spp.) in an episodically hypoxic estuary: implications for individual energetics and trophic dynamics. Marine Biology, 152, 939-957.

Thomas P. \& Rahman M.S. (2009) Chronic Hypoxia Impairs Gamete Maturation in Atlantic Croaker Induced by Progestins through Nongenomic Mecha- 
nisms Resulting in Reduced Reproductive Success. Environmental Science \& Technology, 43, 4175-4180.

Thomas P., Rahman M.S., Khan I.A. \& Kummer J.A. (2007) Widespread endocrine disruption and reproductive impairment in an estuarine fish population exposed to seasonal hypoxia. Proceedings of the Royal Society B-Biological Sciences, 274, 2693-2702.

Trumpickas J., Shuter B.J. \& Minns C.K. (2009) Forecasting impacts of climate change on Great Lakes surface water temperatures. Journal of Great Lakes Research, 35, 454-463.

Valverde J.C., Lopez F.J.M. \& Garcia Garcia B. (2006) Oxygen consumption and ventilatory frequency responses to gradual hypoxia in common dentex (Dentex dentex): basis for suitable oxygen level estimations. Aquaculture, 256, 542-551.

Vanderploeg H.A., Ludsin S.A., Ruberg S.A., Höök T.O., Pothoven S.A., Brandt S.B., Lang G.A., Liebig J.R. \& Cavaletto J.F. (2009) Hypoxia affects spatial distributions and overlap of pelagic fish, zooplankton, and phytoplankton in Lake Erie. Journal of Experimental Marine Biology and Ecology, 381(Suppl. 1), S92-S107.
Vaquer-Sunyer R. \& Duarte C.M. (2008) Thresholds of hypoxia for marine biodiversity. Proceedings of the National Academy of Sciences, 105, 15452-15457.

Wismer D.A. \& Christie A.E. (1987) Temperature Relationships of Great Lakes Fishes: a Data Compilation. Great Lakes Fishery Commission, Ann Arbor, MI, p. 165.

Wu R.S.S. (2002) Hypoxia: from molecular responses to ecosystem responses. Marine Pollution Bulletin, 45, 3545.

Wu R.S.S., Zhou B.S., Randall D.J., Woo N.Y.S. \& Lam P.K.S. (2003) Aquatic hypoxia is an endocrine disruptor and impairs fish reproduction. Environmental Science $\mathcal{E}$ Technology, 37, 1137-1141.

Zhang H., Ludsin S.A., Mason D.M., Adamack A.T., Brandt S.B., Zhang X., Kimmel D.G., Roman M.R. \& Boicourt W.C. (2009) Hypoxia-driven changes in the behavior and spatial distribution of pelagic fish and mesozooplankton in the northern Gulf of Mexico. Journal of Experimental Marine Biology and Ecology, 138(Suppl. 1), S80-S91.

(Manuscript accepted 26 August 2010) 